Volume 5 Number 2, July-December 2021: pg. 121-130.

Fakultas Hukum, Universitas Lampung,

Bandar Lampung, Lampung, Indonesia.

E-ISSN: 2598-3105 P-ISSN: 2723-2581

http://jurnal.fh.unila.ac.id/index.php/cepalo

\title{
LOANS SETTLEMENT AT FEDERAL INTERNATIONAL FINANCE Ltd. (FIF) BANDAR LAMPUNG CITY
}

\section{Mutia Marta Hendriani}

Rotaract Club Lampung of Raden Intan, Indonesia,

E-mail: mutiamartah@gmail.com

Submitted: March 22, 2021; Reviewed: July 1, 2021; Accepted: July 9, 2021

DOI: $10.25041 /$ cepalo.v5no2.2363

\begin{abstract}
There are many ways to purchase a vehicle, including a credit system. However, various problems arise in its application regarding the settlement of bad loans caused by default debtors. This study aims to analyse the efforts made by Federal International Finance Ltd. (FIF) Bandar Lampung City in resolving motor vehicle bad loans due to default debtors. This study uses empirical normative legal research methods and qualitative descriptive methods. The data is obtained from direct observations and interviews, then linked to legal regulations concerning the default problem. The results indicate that Federal International Finance Ltd. has an ideal solution to resolve bad Loans through litigation and non-litigation. Efforts to settle bad loans through non-litigation could be made by giving a subpoena to the debtor. Furthermore, the creditor could take litigation by filing a civil lawsuit against the debtor for default according to Article 1243 of the Civil Code.
\end{abstract}

Keywords: Debtor, Bad Loans Settlement, Financing Agreement, Default.

\section{A. Introduction}

The community's various needs increase along with the economy's expansion due to development. ${ }^{1}$ One of the increasing community's needs is transportation. It could be seen from vehicles' denseness on the highway that causes significant congestion. There are various ways to purchase a vehicle, including using a credit system. Credit could be identified using a credit agreement, which is an agreement between two parties determining the agreed maturity of the credit. ${ }^{2}$ Credit is a provision of bills or money that could be equated, based on the debtors and creditors' agreement and approval or where the bank and other parties should pay off debts with a predetermined time. The agreement is something on that two or more people

\footnotetext{
1 M. Taufich Hidayat, Martin Roestamy, and Endeh Suhartini, "Pengembangan Model Fidusia Terhadap Penitipan Barang Dari Persero Pegadaian Kepada Debitur,” Jurnal Living Law 11, no. 2 (2019): 160-71, https://doi.org/10.30997/jill.v11i2.2110.

2 Anak Agung Intan Wulan Sari, Ida Bagus Putra Atmadja, and Anak Agung Sagung Wiratni Darmadi, "Pelaksanaan Perjanjian Kredit Jaminan Perorangan Terkait Debitur Wanprestasi Pada Bank Perkreditan Rakyat," Kertha Semaya: Journal Ilmu Hukum 3, no. 1 (2015): 1-15, https://ojs.unud.ac.id/index.php/kerthasemaya/article/view/43580.
} 
agree. $^{3}$ An agreement could also be interpreted as a legal act in which one person is much more binding on another. ${ }^{4}$ A default occurs when the debtors fail to carry out the terms of the agreement. ${ }^{5}$ Therefore, maintaining a sense of security and the benefits of credit is essential. ${ }^{6}$ There is a consumer financing system in place for credit provision. ${ }^{7}$ Therefore, finance provides credit in order to profit. Financial institutions are relatively new institutions compared to other conventional financial institutions. ${ }^{8}$

Financing institutions are emphasised in the financing function, which could provide capital goods and funds without withdrawing resources from the public. ${ }^{9}$ Policies in developing activities such as financing institutions are regulated by Presidential Regulation No. 08 of 2009 concerning Financing Institutions and the Minister of Finance's Decree No. $1251 /$ KMK.013.1998/ formally could be an alternative for the initial payment. This is an official statement by the financial services sector. ${ }^{10}$

Financing procurement could impede by increasing business transactions between consumer finance companies and debtors (consumers). Based on the consumer financing agreement signed by both parties, the transaction does not always proceed as expected. In the case of credit, consumer finance companies had difficulty requesting installations from debtors for various reasons. If this occurs, the consumer finance company (the creditor) should not demand that the instalments be paid immediately. However, the debtor should pay the agreed-upon instalments with interest. If the debtor does not fulfil this obligation by paying instalments, it could be bad loans due to default. ${ }^{11}$

Bad Loans is different from arrears or delays in payments. There is bad faith from the debtor, inability to pay instalments, and coercion in bad loans. Due to injustice on the debtor and unresolved problems, bad loans necessitate a prudent solution so that the parties are not harmed, namely litigation or non-litigation. Bad loans at consumer finance companies could also occur due to insider fraud collusion with Irresponsible dealers. Fraudulent surveyors (account officers) violate standard operating procedures (SOPs) by not visiting potential customers (plant visits), manipulating prospective customers' data, failing to ensure the debtors' existence properly, and imitating the consumer's signature on the agreement deed. Even surveyor fraud could invalidate the credit agreement between the company and the consumer.

Consumer finance companies issue a warning letter (subpoenas) to the debtor in the event of a default that causes bad loans. ${ }^{12}$ However, the finance company would take or confiscate

\footnotetext{
${ }^{3}$ Christoph Trebesch and Michael Zabel, "The Output Costs of Hard and Soft Sovereign Default," European

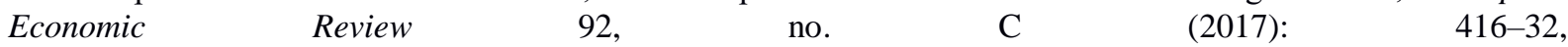
http://www.sciencedirect.com/science/article/pii/S0014292116301817.

4 A Qirom Syamsudin Meliala, Pokok-Pokok Hukum Perjanjian Beserta Perkembangannya (Yogyakarta: Liberty, 1985): 1.

${ }^{5}$ R. Soebekti, Hukum Perjanjian (Jakarta: Intermasa, 2005): 1-100.

${ }^{6}$ Edy Putra Tjeman, Kredit Perbankan Suatu Tinjauan Yuridis (Jakarta: Pradnya Paramita, 2001): 1-105.

${ }^{7}$ Munir Fuadi, Hukum Tentang Pembiayaan Dalam Teori Dan Praktek (Bandung: PT Citra Aditya Bakti, 2002): 163.

${ }^{8}$ I Made Aditia Warmadewa and I Made Udiana, "Akibat Hukum Wanprestasi Dalam Perjanjian Baku," Kertha Semaya: Journal Ilmu Hukum $4, \quad$ no. $\quad 2 \quad$ (2016): https://ojs.unud.ac.id/index.php/kerthasemaya/article/view/20545.

${ }^{9}$ Sunaryo, Hukum Lembaga Pembiayaan (Jakarta: Sinar Grafika, 2014): 1-2.

${ }^{10}$ Richard Burton Simatupang, Aspek Hukum Dalam Bisnis (Jakarta: PT Rineka Cipta, 2003): 117.

${ }^{11}$ Algadita Fatmala, “Analisis Yuridis Penggunaan Surat Kuasa Membebankan Hak Tanggungan (SKMHT) Bagi Kreditur Dalam Menangani Debitur Wanprestasi," Privat Law 3, no. 1 (2013): 14-21, https://www.neliti.com/publications/26542/analisis-yuridis-penggunaan-surat-kuasa-membebankan-haktanggungan-skmht-bagi-kr.

12 Asuan, "Penyelesaian Terhadap Debitur Wanprestasi Dalam Perjanjian Gadai," Solusi 18, no. 1 (2020): 12838, https://doi.org/10.36546/solusi.v18i1.254.
} 
the goods with the Debt Collector's assistance if the debtor ignores the warning letter. Based on the contract agreement, debt collectors from a company may take the agreed goods without the owner's consent. Debt collectors are not prohibited in consumer finance companies if procedures, norms, and rules are followed. Therefore, the public should comply with contracts made to consumer finance companies and debt collectors should not violate the law in carrying out their duties. Federal International Finance Ltd. (FIF) Bandar Lampung City is a consumer finance company that handles many bad loans cases due to the debtor's default.

Credit agreements often result in defaults that cause losses to creditors because the debtor does not fulfil the agreed obligations. As happened with Federal International Finance Ltd. Bandar Lampung City, there are issues between debtors and creditors because creditors provide debtors with certain conditions, namely guarantees. However, the debtor's guarantee was lost in a motorbike; then, the debtor did not pay off the loan. ${ }^{13}$

From the explanation above, this study aims to analyse the efforts made by Federal International Finance Ltd. (FIF) Bandar Lampung City in resolving motor vehicle bad loans due to default debtors. This research was conducted using normative legal methods. ${ }^{14}$ This research uses a qualitative descriptive method where data is obtained from direct observations and interviews, then linked to legal regulations concerning the default problem. ${ }^{15}$

\section{B. Discussion}

\section{Provisions Regarding Motor Vehicle Debt at Federal International Finance Ltd. (FIF) Bandar Lampung City}

A credit provision was a term and condition imposed on prospective debtors by Federal International Finance Ltd. before applying for credit. Federal International Finance Ltd. provisions consist of the following:

a. General terms:

1) The prospective debtor is between 21-60 years, and there is a down payment.

2) Have a credit term of 1 to 5 years.

3) Prospective debtors' salaries exceed four instalments.

b. General Conditions:

1) There is a letter of approval

2) There is a business certificate and salary slip.

3) Photocopy of Identity Card (KTP)

4) Copy of Family Card (KK)

5) Photocopy of land and building tax (PBB).

Based on the explanation above, the general terms and conditions could be burdensome for prospective debtors, such as the prospective debtor's salary exceeding four instalments.

c. Fulfil the creditor's form.

\footnotetext{
13 Siti Malikhatun Badriyah et al., "Implementation of the Constitutional Court Decision Regarding the Execution of Fiduciary Guarantees and Inclusion of Default Clauses in Indonesia," International Journal of Criminology and Sociology 10 (2021): 33-38, https://doi.org/10.6000/1929-4409.2021.10.05.

14 Shavira Ramadhanneswari, R. Suharto, and Hendro Saptono, "Penarikan Kendaraan Bermotor Oleh Perusahaan Pembiayaan Terhadap Debitur Yang Mengalami Kredit Macet (Wanprestasi) Dengan Jaminan Fidusia Ditinjau Dari Aspek Yuridis," Diponegoro Law Journal 6, no. 2 (2017): 1-14, https://ejournal3.undip.ac.id/index.php/dlr/article/view/17434.

15 Abdulkadir Muhammad, Hukum Dan Penelitian Hukum (Bandung: PT. Citra Aditya Bakti, 2004): 202.
} 
One of the steps passed to assess prospective debtors' eligibility is credit-granting rules. ${ }^{16}$ The credit-granting rules for Federal International Finance Ltd. consist of seven stages including:

a. In the credit application stage, the prospective debtor visits the dealer before going to Federal International Finance Ltd. to purchase a vehicle on credit.

b. In the financing application stage, the prospective debtor would fill out a form and fulfil the requirements to be submitted to Federal International Finance Ltd.

c. In the checking stage, a survey is conducted directly to the prospective debtor's location to assess the consumer's actual condition.

d. In the credit analysis stage, Federal International Finance Ltd. implements the credit principle, namely the 5C principle (Capital, Condition, Character, Capacity, and Collateral).

e. Federal International Finance Ltd. has the right to take goods as collateral to avoid consumers who do not pay instalments and could not pay off their obligations.

f. In the payment stage, Federal International Finance Ltd. pays to purchase a vehicle from the dealer when the debtor has received the goods.

g. In the monitoring or billing payments stage, the debtor's payments are in instalments according to a predetermined time.

In conclusion, the procedure for granting vehicle debt to Federal International Finance Ltd. is complicated for consumers who would apply for credit because consumers should first visit the dealer before going to Federal International Finance Ltd. ${ }^{17}$

\section{Causes of Default}

Consumer indiscipline causes credit problems. Banks and financial institutions are also stuck in credit problems. According to the Human Resources Development (HRD) of Federal International Finance Ltd. Bandar Lampung, international tax policies are reliable in risk management by maintaining the customer familiarity principle, namely by applying the $5 \mathrm{C}$ procedures, so that bad loans remain at a safe level. ${ }^{18}$ The whole process is a general credit trust process carried out by FIFGROUP before deciding to provide financing facilities. However, sometimes in the middle of the agreed period, consumers could not pay the instalments that should be their obligations, causing bad loans. ${ }^{19}$ Based on the results of interviews at Federal International Finance Ltd. Bandar Lampung, the author obtained several factors that could lead to default, including:

a. Economy

The economy is the leading cause of default problems. ${ }^{20}$ The default could occur in consumers experiencing difficulties and cause bad income. ${ }^{21}$

b. Instalment payment funds are used for other things

\footnotetext{
${ }^{16}$ Amin Rais, "Penyelesaian Debitur Wanprestasi Dengan Jaminan Fidusia Di Bank BRI Unit Simpang Pebem Kota Palembang" (Universitas Muhammadiyah Palembang, 2019), http://repository.umpalembang.ac.id/id/eprint/5962/.

${ }^{17}$ Ika Dharma Citta Rahayu, "Penyelesaian Wanprestasi Perjanjian Kredit Dengan Jaminan Hak Tanggungan Oleh Debitur Dihubungkan Dengan Pasal 1320 KUHPerdata Dan UU No 4 Tahun 1996 Tentang UU Hak Tanggungan (Studi Kasus Di Bank Perkreditan Rakyat Magga Jaya Utama Taman Cibodas Kota Tan" (Universitas Pamulang, 2017), http://eprints.unpam.ac.id/5351/.

${ }^{18}$ Interview with Human Resource Development (HRD) PT FIF Kota Bandar Lampung on 13 January 2021.

${ }^{19}$ Igor Livshits, "Recent Developments in Consumer Credit and Default Literature," Journal of Economic Surveys 29, no. 4 (2015): 594-613, https://doi.org/10.1111/joes.12119.

${ }^{20}$ Benjamin Hébert and Jesse Schreger, "The Costs of Sovereign Default: Evidence from Argentina," American Economic Review 107, no. 10 (2017): 3119-3145, https://doi.org/10.1257/aer.20151667.

${ }^{21}$ Jhony Palapa, "Penyelesaian Debitur Wanprestasi Dengan Jaminan Fidusia," Sol Justicia 3, no. 1 (2020): 2638, http://ojs.ukb.ac.id/index.php/sj/article/view/122.
} 
Another factor that causes default is using instalment funds for other things. According to the Human Resource Development (HRD) of Federal International Finance Ltd. Bandar Lampung, several parties emerged due to urgent circumstances. Based on this, the following table description could be seen:

\section{Table 1. Federal International Finance Ltd. Bandar Lampung's percentage of total factors causing debtor default:}

\begin{tabular}{|c|c|c|}
\hline No. & Factors Causing Default & Total Percentage \\
\hline 1. & Economic Factor & $60 \%$ \\
\hline 2. & Funds are used to pay other instalments & $40 \%$ \\
\hline \multicolumn{2}{|c|}{ (Data source Federal International Finance Ltd. Bandar Lampung) } \\
\hline
\end{tabular}

Default against consumer financing agreement at Federal International Finance Ltd. includes, among others:

a. A debtor could not fulfil obligations following the agreement; ${ }^{22}$

b. A debtor could not fulfil the care and protection of the goods guaranteed from damage, loss, and destruction;

c. Debtors borrowed, guaranteed, or charged with collateral rights; ${ }^{23}$

d. The collateral would be taken and confiscated if the parties did not follow the agreement.

\section{Bad Loans Settlement Efforts at Federal International Finance Ltd. Bandar Lampung City}

According to the Human Resource Development (HRD) of Federal International Finance Ltd. Bandar Lampung, there are several ways to meet the needs of bad loans in consumer financing, including litigation and non-litigation. ${ }^{24}$ Attempts to settle the bad loan through non-litigation could be made by giving a subpoena to debtors. The summons gives the debtor two weeks to pay off the bad loans, or the debtor's motor vehicle would be auctioned. Furthermore, the creditor could take litigation by filing a civil court lawsuit against the debtor for default under Civil Code Article 1243, along with a claim for compensation if the bad loans remain uncollectible. ${ }^{25}$

Non-litigation settlement is possible through preventive efforts, namely actions taken to anticipate the emergence of bad loans and early warning, namely an initial effort to deal with defaulting debtors' bad loans. ${ }^{26}$ There are eight negative things listed in the standard clauses that business owners are not permitted to apply to consumers under article 18 paragraph 1 of Law Number 8 of 1999 concerning consumer protection, including:

a. Declare the transfer of business actors' responsibility.

\footnotetext{
${ }^{22}$ Christian Lohmann and Thorsten Ohliger, "Nonlinear Relationships in a Logistic Model of Default for a HighDefault Instalment Portfolio," Journal of Credit Risk 14, no. 1 (2018): 45-68, https://doi.org/10.21314/JCR.2017.232.

23 Lobna Abid, Mohamed Najib Ouertani, and Sonia Zouari-Ghorbel, "Macroeconomic and Bank Specific Determinants of Household's Non-Performing Loans in Tunisia," Procedia Economics and Finance 13 (2014): 58-68, 10.1016/S2212-5671(14)00430-4.

${ }^{24}$ Interview with Human Resource Development (HRD) PT FIF Kota Bandar Lampung on 13 January 2021.

25 Mitia Intansari and I Made Walesa Putra, "Kedudukan Kreditur Pemegang Hak Tanggungan Dalam Hal Debitur Wanprestasi," Kertha Semaya: Journal Ilmu Hukum 5, no. 2 (2016): 1-7, https://ojs.unud.ac.id/index.php/kerthasemaya/article/view/20941.

26 Mária Mišanková, Erika Spuchl'akova, and Katarina Frajtova-Michalikova, "Determination of Default Probability by Loss Given Default," Procedia Economics and Finance 26 (2015): 411-17, https://doi.org/10.1016/S2212-5671(15)00815-1.
} 
b. To declare that business actors have the right to refuse refunds money paid for goods and services purchased by consumers;

c. To declare that business actors have the right to refuse refunds for goods and services purchased by consumers;

d. Declare a power of attorney from consumers to business actors to take all unilateral actions related to goods purchased in instalments;

e. Regulates the matter of proving the loss of goods or services usage purchased by consumers;

f. Allows business actors to reduce services benefits;

g. Declaring that consumers are subject to new regulations imposed unilaterally by business actors when consumers use the services purchased; and

h. Declaring that the consumer authorises the business actor to impose mortgage, lien, or security rights on goods purchased in instalments.

According to the author's research results, the consumer financing agreement made by the creditor and debtor does not contain negative violations as stated in Law Number 8 of 1999 concerning Consumer Protection. This is evidenced by Federal International Finance Ltd.'s good faith in implementing consumer financing agreements. Federal International Finance Ltd. has complied with Article 4 of Law Number 8 of 1999 concerning Consumer Protection which states that before entering into a contract agreement, the finance company should explain the contents of the consumer financing agreement to the debtor.

Based on the freedom of contract principle, the consumer financing agreement follows existing limitations such as not contradicting the law, public order and morality. Federal International Finance Ltd. should offer upon the consumers' availability in signing the consumer financing agreement after explaining the standard agreement contents during the pre-contractual phase. If the consumer refuses the content of the financing contract, Federal International Finance Ltd. may not force the debtor to sign it. The debtor is free to use their rights under Article 4 of Law Number 8 of 1999 concerning Consumer Protection.

Furthermore, according to the balance and proportionality principle, the parties' rights and obligations should be balanced following the agreement. The balance principle requires both parties to fulfil and implement the consumer financing agreement. The creditor had the authority to demand repayment of achievements through the debtor's wealth. In addition, the creditor is obligated to enforce the agreement in good faith. Creditors' strong position is followed by the obligation to act in good faith, resulting in a balanced position for creditors and debtors. The proportionality principle is oriented to the parties' relationship and interests, namely that the parties rights and obligations should follow the proportion or a portion thereof.

Consumer financing agreement would be null and void and have no legal binding if its implementation is contrary to Law Number 8 of 1999 concerning Consumer Protection and principles such as freedom of contract, balance, and proportionality. Creditors might be subject to article 1365 of the Civil Code because it was an act against the law. However, from the author's research results, the consumer financing agreement made by Federal International Finance Ltd. approved and signed by the debtor already refers to Law Number 8 of 1999 concerning Consumer Protection and principles such as freedom of contract, balance, and proportionality.

According to an interview with the Human Resource Development (HRD) of Federal International Finance Ltd. Bandar Lampung, there are internal and external obstacles to withdrawing the vehicle. Internal obstacles arise from problems within Federal International Finance Ltd. which include a flawed performance system, and other obstacles such as:

a. debt collectors were lazy in collecting debts from debtors; 
b. The surveyor was insufficiently detailed in conducting interviews with the debtor before the financing company approved the financing application; and

c. The operations department calculates principal instalment payments and interest on defaulted debtors with inaccuracy.

Internal obstacles resolution to bad loans at Federal International Finance Ltd. is that parties who made internal errors receive warnings and sanctions under applicable regulations. However, there were also external obstacles that could impede the collection and withdrawal of motor vehicles. External obstacles occur from the debtor, specifically unlawful acts against the consumer financing contract agreed to by Federal International Finance Ltd. and the debtor. These external obstacles include:

a. the motor vehicle has been sold to a third party;

b. the facility recipient has changed address (unknown), and the goods' identity has been changed;

c. debtors are challenging to find;

d. motorised vehicles have been mortgaged; and

e. Motorised vehicles are lost due to intentional or unintentional.

The debtor was not in default if the motor vehicle was lost by accident, such as theft or overmacht. In contrast, the billing would still be carried out if the motor vehicle is intentionally lost, such as being rented out. The debtor should pay the principal and interest instalments until it is paid off. The Head Collector of Federal International Finance Ltd. would collaborate with the Debt Collector and authorities to find missing motorised vehicles and collaborate with parking attendants to compile a license plates list of missing vehicles. The company then made a letter blocking the $\mathrm{STNK}^{27}$ or $\mathrm{BPKB}^{28}$ to the Regional Police Office.

There was an ideal settlement of bad loans with these various obstacles. If there were normative obstacles at Federal International Finance Ltd., the financing company (the creditor) could be subject to Article 1365 of the Civil Code. This article stated that "Every act that violates the law and causes harm to another person requires the guilty party to compensate for the loss." Based on an adequate theory, compensation is all causes that result in consequences should be punished. However, according to the author's research results, Federal International Finance Ltd. has no normative obstacles and follows applicable laws.

\section{Conclusion}

Litigation and non-litigation were used to settle bad loans at Federal International Finance Ltd. Non-litigation is accomplished by giving subpoena letters to debtors with a twoweek time limit to settle bad loans, or motorised vehicles would be auctioned. Furthermore, if the bad loans are resolved through litigation, the creditor would file a default suit in the form of compensation to the debtor in a civil court under Article 1243 of the Civil Code.

\section{Acknowledgement}

The researcher would like to thank all parties involved in this research. Special thanks to Federal International Finance Ltd. (FIF) Bandar Lampung City has been permitted to conduct research. Thanks to the Head of Human Resource Development (HRD) Federal International Finance Ltd. (FIF) for willing to become respondents and provide their opinions. Thanks also to all those who have contributed to the research.

\footnotetext{
${ }^{27}$ STNK stands for Surat Tanda Nomor Kendaraan, which means Vehicle Registration Certificate

${ }^{28}$ BPKB stands for Buku Pemilik Kendaraan Bermotor, which means Vehicle Title of Indonesia
} 


\section{REFERENCES}

Abid, Lobna, Mohamed Najib Ouertani, and Sonia Zouari-Ghorbel. "Macroeconomic and Bank Specific Determinants of Household's Non-Performing Loans in Tunisia." Procedia Economics and Finance 13 (2014): 58-68. 10.1016/S2212-5671(14)00430-4.

Asuan. "Penyelesaian Terhadap Debitur Wanprestasi Dalam Perjanjian Gadai." Solusi 18, no. 1 (2020): 128-38. https://doi.org/10.36546/solusi.v18i1.254.

Badriyah, Siti Malikhatun, R. Suharto, Marjo, Retno Saraswati, and Muhammad Shafiyuddin Wafi. "Implementation of the Constitutional Court Decision Regarding the Execution of Fiduciary Guarantees and Inclusion of Default Clauses in Indonesia." International Journal of Criminology and Sociology 10 (2021): 33-38. https://doi.org/10.6000/19294409.2021.10.05.

Fatmala, Algadita. "Analisis Yuridis Penggunaan Surat Kuasa Membebankan Hak Tanggungan (SKMHT) Bagi Kreditur Dalam Menangani Debitur Wanprestasi." Privat Law 3, no. 1 (2013): 14-21. https://www.neliti.com/publications/26542/analisis-yuridispenggunaan-surat-kuasa-membebankan-hak-tanggungan-skmht-bagi-kr.

Fuadi, Munir. Hukum Tentang Pembiayaan Dalam Teori Dan Praktek. Bandung: PT Citra Aditya Bakti, 2002: 163.

Hébert, Benjamin, and Jesse Schreger. "The Costs of Sovereign Default: Evidence from Argentina." American Economic Review 107, no. 10 (2017): 3119-3145. https://doi.org/10.1257/aer.20151667.

Hidayat, M. Taufich, Martin Roestamy, and Endeh Suhartini. "Pengembangan Model Fidusia Terhadap Penitipan Barang Dari Persero Pegadaian Kepada Debitur." Jurnal Living Law 11, no. 2 (2019): 160-71. https://doi.org/10.30997/jill.v11i2.2110.

Intansari, Mitia, and I Made Walesa Putra. "Kedudukan Kreditur Pemegang Hak Tanggungan Dalam Hal Debitur Wanprestasi." Kertha Semaya: Journal Ilmu Hukum 5, no. 2 (2016): 1-7. https://ojs.unud.ac.id/index.php/kerthasemaya/article/view/20941.

Livshits, Igor. "Recent Developments in Consumer Credit and Default Literature." Journal of Economic Surveys 29, no. 4 (2015): 594-613. https://doi.org/10.1111/joes.12119.

Lohmann, Christian, and Thorsten Ohliger. "Nonlinear Relationships in a Logistic Model of Default for a High-Default Instalment Portfolio." Journal of Credit Risk 14, no. 1 (2018): 45-68. https://doi.org/10.21314/JCR.2017.232.

Meliala, A Qirom Syamsudin. Pokok-Pokok Hukum Perjanjian Beserta Perkembangannya. Yogyakarta: Liberty, 1985: 1.

Mišanková, Mária, Erika Spuchl’akova, and Katarina Frajtova-Michalikova. "Determination of Default Probability by Loss Given Default." Procedia Economics and Finance 26 (2015): 411-17. https://doi.org/10.1016/S2212-5671(15)00815-1.

Muhammad, Abdulkadir. Hukum Dan Penelitian Hukum. Bandung: PT. Citra Aditya Bakti, 2004: 202.

Palapa, Jhony. "Penyelesaian Debitur Wanprestasi Dengan Jaminan Fidusia." Sol Justicia 3, no. 1 (2020): 26-38. http://ojs.ukb.ac.id/index.php/sj/article/view/122. 
Rahayu, Ika Dharma Citta. "Penyelesaian Wanprestasi Perjanjian Kredit Dengan Jaminan Hak Tanggungan Oleh Debitur Dihubungkan Dengan Pasal 1320 KUHPerdata Dan UU No 4 Tahun 1996 Tentang UU Hak Tanggungan (Studi Kasus Di Bank Perkreditan Rakyat Magga Jaya Utama Taman Cibodas Kota Tan.” Universitas Pamulang, 2017. http://eprints.unpam.ac.id/5351/.

Rais, Amin. "Penyelesaian Debitur Wanprestasi Dengan Jaminan Fidusia Di Bank BRI Unit Simpang Pebem Kota Palembang." Universitas Muhammadiyah Palembang, 2019. http://repository.um-palembang.ac.id/id/eprint/5962/.

Ramadhanneswari, Shavira, R. Suharto, and Hendro Saptono. "Penarikan Kendaraan Bermotor Oleh Perusahaan Pembiayaan Terhadap Debitur Yang Mengalami Kredit Macet (Wanprestasi) Dengan Jaminan Fidusia Ditinjau Dari Aspek Yuridis.” Diponegoro $\begin{array}{llllll}\text { Law Journal } & 6, & \text { no. } & 2 & \text { (2017): } & 1-14 .\end{array}$ https://ejournal3.undip.ac.id/index.php/dlr/article/view/17434.

Sari, Anak Agung Intan Wulan, Ida Bagus Putra Atmadja, and Anak Agung Sagung Wiratni Darmadi. "Pelaksanaan Perjanjian Kredit Jaminan Perorangan Terkait Debitur Wanprestasi Pada Bank Perkreditan Rakyat.” Kertha Semaya: Journal Ilmu Hukum 3, no. 1 (2015): 1-15. https://ojs.unud.ac.id/index.php/kerthasemaya/article/view/43580.

Simatupang, Richard Burton. Aspek Hukum Dalam Bisnis. Jakarta: PT Rineka Cipta, 2003: 117.

Soebekti, R. Hukum Perjanjian. Jakarta: Intermasa, 2005: 1-100.

Sunaryo. Hukum Lembaga Pembiayaan. Jakarta: Sinar Grafika, 2014: 1-2.

Tjeman, Edy Putra. Kredit Perbankan Suatu Tinjauan Yuridis. Jakarta: Pradnya Paramita, 2001: 1-105.

Trebesch, Christoph, and Michael Zabel. "The Output Costs of Hard and Soft Sovereign Default." European Economic Review 92, no. C (2017): 416-32. http://www.sciencedirect.com/science/article/pii/S0014292116301817.

Warmadewa, I Made Aditia, and I Made Udiana. "Akibat Hukum Wanprestasi Dalam Perjanjian Baku." Kertha Semaya: Journal Ilmu Hukum 5, no. 2 (2016): 1-6. https://ojs.unud.ac.id/index.php/kerthasemaya/article/view/20545. 
